\title{
Pemanfaatan Aplikasi Smartphone: Meningkatkan Keterampilan Service Atas
} Bola Voli

\author{
Rafdlal Saeful Bakhri ${ }^{1}$, Didih Nurjaman ${ }^{2}$, Arfin Deri Listiandi ${ }^{3}$, Rifqi Festiawan ${ }^{4}$, \\ Dimas Awal Ginanjar ${ }^{5}$ \\ ${ }^{12}$ STKIP Bina Mutiara Sukabumi, Indonesia. \\ ${ }^{34}$ Fakultas Ilmu-ilmu Kesehatan, Universitas Jenderal Soedirman, Indonesia. \\ ${ }^{5}$ SMAN 1 Ciracap Sukabumi, Indonesia.

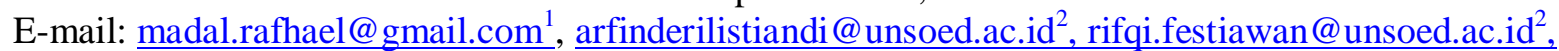 \\ ginanjaralgi@gmail.com ${ }^{3}$
}

Menerima: 30 Mei 2020; Revisi: 01,Oktober,2020; Diterima: 14,Oktober, 2020

https://doi.org/10.24036/ MensSana.050220.01

\begin{abstract}
Service is a basic technique that is very important because with this technique the game starts. The blackness of the overhand serve skill of extracurricular students of course has to be handled immediately and also appropriately based on student's characteristics who are a teenager. The strong tendency of the teenager to the smartphone is one of the aspects that need to be considered and to be functioned to help exercise. The purpose of this research is to make use of smartphone application 'Home workout no equipment' in exercising arm muscle to increase volleyball overhand serve skill. This research used a quantitative quasi-experiment method, used One Group Pretest and Posttest Design. The number of sample research is 20 male students member of volleyball extracurricular in Ciracap 1 State Junior High School Sukabumi. The research instrument was an overhand serve test. This research is conducted in 16 meetings, divided into three times meetings in a week. Data analysis which is used to test the hypothesis is a paired sample T-test. Data analysis showed a significant value $<0,05$ it indicates that there is a significant effect of arm muscle strength exercise by making use of smartphone application to the improvement overhand serve volleyball of extracurricular students.
\end{abstract}

Keywords: smartphone application, overhand serve skill, volleyball.

\section{Abstrak}

Service merupakan teknik dasar yang sangat penting, karena merupakan teknik dasar yang memulai suatu permainan. Kurangnya keterampilan service atas pada siswa peserta ekstrakurikuler tentunya perlu segera ditangani melalui latihan yang tepat dan juga sesuai dengan karakteristik siswa yang merupakan remaja. Kecenderungan remaja yang sangat erat dengan smartphone merupakan suatu aspek yang perlu dipertimbangkan dan dimanfaatkan untuk menunjang latihan. Tujuan penelitian ini adalah memanfaatkan aplikasi smartphone "Home Workout no Equipment" dalam melatih kekuatan otot lengan guna meningkatkan keterampilan service atas bola voli. Penelitian ini menggunakan metode kuantitatif kuasi eksperimen, desain penelitian menggunakan One Group Pretest Posttest Design. Sampel penelitian sejumlah 20 orang siswa putra peserta ekstrakurikuler bola voli SMPN 1 Ciracap Kabupaten Sukabumi. Instrumen penelitian yang digunakan adalah tes service atas. Penelitian dilakukan sebanyak 16 kali pertemuan, yang terdiri dari 3 kali dalam 1 minggu. Analisis data yang digunakan untuk menguji hipotesis adalah paired sample $t$ test. Hasil analisis data menunjukan nilai signifikansi $<0,05$ menunjukan bahwa terdapat pengaruh yang signifikan latihan kekuatan otot lengan dengan memanfaatkan aplikasi smartphone terhadap peningkatan keterampilan service atas bola voli pada siswa peserta ekstrakurikuler SMPN 1 Ciracap Kabupaten Sukabumi.

Kata Kunci: Aplikasi Smartphone, Keterampilan Service Atas, Bola Voli.

\section{PENDAHULUAN}

Bola voli di Indonesia merupakan salah satu cabang olahraga permainan yang sudah dikenal sejak lama dan diminati diberbagai kalangan. Permainan bola voli termasuk pada net game, berusaha untuk menempatkan bola agar 
jatuh dilapangan permainan lawan atau membuat lawan tidak dapat mengembalikan bola. Seperti kebanyakan jenis olahraga net game, kemenangan dalam permainan bola voli juga ditentukan berdasarkan tim yang terlebih dahulu mencapai skor tertentu.

Dalam bola voli untuk memperoleh kemenangan dalam satu set dimenangkan oleh tim yang mencetak skor pertama 25 point dengan keunggulan minimum dua point (FIVB, 2016, p. 22) tim yang memenangkan set lebih banyak dinyatakan sebangai pemenang. Untuk dapat memenangkan suatu pertandingan tentunya perlu didukung dengan penampilan permainan yang baik. Dalam mewujudkan permainan yang baik ditunjang oleh berbagai faktor, salah satunya keterampilan teknik dasar.

Dalam permainan bola voli terdapat empat teknik dasar, yaitu: servis, passing, blocking, dan smash (Edwan et al., 2017, p. 65). Tentunya untuk dapat memperoleh penampilan yang baik semua teknik dasar tersebut perlu dikuasai oleh setiap pemain. Teknik dasar service merupakan teknik dasar yang sangat penting, karena merupakan teknik dasar yang memulai suatu permainan (Gazali, 2016, p. 2). Kegagalan seorang pemain dalam melakukan service akan membuat lawan mendapatkan point dengan mudah. Dalam suatu pertandingan bola voli yang terlalu banyak kegagalan service, membuat permainan tidak menarik dan relatif akan berakhir dengan cepat.

Terlebih lagi dengan sistem rally point (FIVB, 2016, p. 22) service bukan hanya berperan sebagai teknik dasar yang mengawali suatu permainan, akan tetapi juga sebagai serawan awal yang bertujuan untuk memperoleh point (Gazali, 2016, p. 2; Iskandar, 2016, p. 23). Setidaknya service merupakan upaya pertama untuk menyulitkan lawan mengembalikan bola, sehingga akan memudakan tim untuk melakukan serangan yang berpotensi untuk menghasilkan point. Keterampilan service mutlak perlu dikuasai oleh para pemain dalam berbagai tingkatan, termasuk siswa ekstrakurikuler bola voli.

Peserta Ekstrakurikuler bola voli pada tingkat SMP tentunya juga harus menguasai teknik dasar service dengan baik. Meskipun sebenarnya terdapat beberapa jenis teknik, diantaranya underhand serve, overhand serve, dan jump service, akan tetapi untuk tingkat ini dianjurkan siswa sudah mampu menguasai teknik overhand serve (service atas). Berdasarkan pengamatan peneliti pada peserta ekstrakurikuler SMPN I Ciracap keterampilan teknik service atas masih kurang baik. Terutama pada saat pertandingan, masih terjadi kegagalan dalam melakukan service atas. Salah satu faktor yang menunjang penguasaan keterampilan service atas adalah kekuatan otot lengan (Gazali, 2016, p. 2). Berdasarkan hal tersebut diperlukan suatu latihan yang tepat untuk siswa SMP peserta ekstrakurikuler agar dapat meningkatkan keterampilan service atas dalam permainan bola voli.

Sesuai dengan perkembangan teknologi saat ini siswa SMP yang juga termasuk kategori remaja sangat erat dengan smartphone. Penggunaan smartphone pada remaja dilakukan setiap hari, baik di lingkungan rumah, lingkungan bermain, dan juga di sekolah, sebagian besar digunakan untuk mengakses social media dan game (Muflih et al., 2017, p. 16). Berbagai aktivitas remaja saat ini yang hampir selalu bersentuhan dengan smartphone tidak dapat dibendung, karena hal tersebut merupakan salah satu bentuk kemajuan teknologi yang berdampak pada remaja. Akan tetapi hal tersebut harus dapat diarahkan pada suatu aktivitas yang lebih baik lagi, seperti memanfaatkan smartphone sebagai media pendukung latihan olahraga.

Dalam bidang keolahragaan, terdapat berbagai aplikasi smartphone yang dapat digunakan untuk menunjang latihan, aplikasi tersebut termasuk pelacak kebugaran, monitor detak jantung, penghitung langkah, program latihan, dan aplikasi pembinaan (Azar et al., 2013).

Meskipun sebagian besar siswa menggunakan smartphone untuk mengakses media social dan game, akan tetapi hal ini dapat digunakan sebagai salah satu pertimbangan untuk memanfaatkan aplikasi smartphone dalam latihan, dalam hal ini latihan kekuatan otot lengan untuk meningkatkan keterampilan service atas bola voli. Salah satu aplikasi smartphone yang dapat dimanfaatkan untuk latihan tersebut adalah "Home work out no equipment".

Aplikasi smartphone Home work out no equipment dikembangkan oleh Leap Fitness Group yang merupakan perusahaan pengembang aplikasi seluler kebugaran dan kesehatan. Aplikasi ini menyediakan berbagai bentuk latihan yang disajikan dalam bentuk animasi gerakan yang harus dilakukan dalam waktu atau repetisi 
tertentu. Aplikasi dapat digunakan pada smartphone berbasis Android atau iOS.

Kecenderungan remaja terhadap smartphone harus diarahkan pada kegiatan yang lebih positif. Diperlukan suatu upaya yang dapat mengintegrasikan penggunaan smartphone dengan kegiatan positif para remaja agar dapat menghasilkan suatu pencapaian yang lebih baik. Tidak terkecuali para peserta ekstrakurikuler bola voli yang juga merupakan remaja memiliki potensi untuk menggunakan smartphone sebagai suatu media pendukung latihan bola voli. Sesuai dengan pemaparan sebelumnya, salah satu aspek yang perlu ditingkatkan adalah keterampilan teknik dasar service atas.

Memanfaatkan aplikasi smartphone Home work out no equipment untuk menunjang latihan siswa dalam meningkatkan keterampilan service atas merupakan salah satu bentuk upaya untuk mengarahkan siswa pada kegiatan yang lebih positif. Penelitian terkait yang meneliti mengenai kekuatan otot lengan dengan keterampilan service atas sudah cukup banyak dilakukan, seperti penelitian (Gazali, 2016; Iskandar, 2016; Pahrian \& Esser, 2017). Akan tetapi penelitian yang memanfaatkan aplikasi smartphone untuk melatih kekuatan otot lengan guna meningkatkan keterampilan service atas masih sangat terbatas.
Berdasarkan hal tersebut peneliti beranggapan penelitian ini penting untuk dilakukan.

\section{METODE}

Penelitian ini menggunakan pendekatan kuantitatif, kuasi ekperimen. Desain penelitian yang digunakan adalah One Group Pretest Posttest Design.

$\mathrm{T} 1$

$x$

$\mathrm{T} 2$

Gambar 1. One Group Pretest Posttest Design Sumber: (Maksum, 2012, p. 97)

Keterangan:

$\mathrm{T} 1=$ Pretest keterampilan service atas,

$\mathrm{X}=$ Treatment latihan kekuatan otot lengan dengan memanfaatkan aplikasi smartphone "Home Workout no Equipment",

$\mathrm{T} 2=$ Posttest keterampilan service atas Sampel penelitian yang digunakan adalah 20 orang siswa putra peserta ekstrakurikuler bola voli SMP Negeri 1 Ciracap Kabupaten Sukabumi. Pemilihan sampel tersebut menggunakan teknik purposive sampling dengan kriteria utama adalah siswa putra yang aktif mengikuti kegiatan ekstrakurikuler.

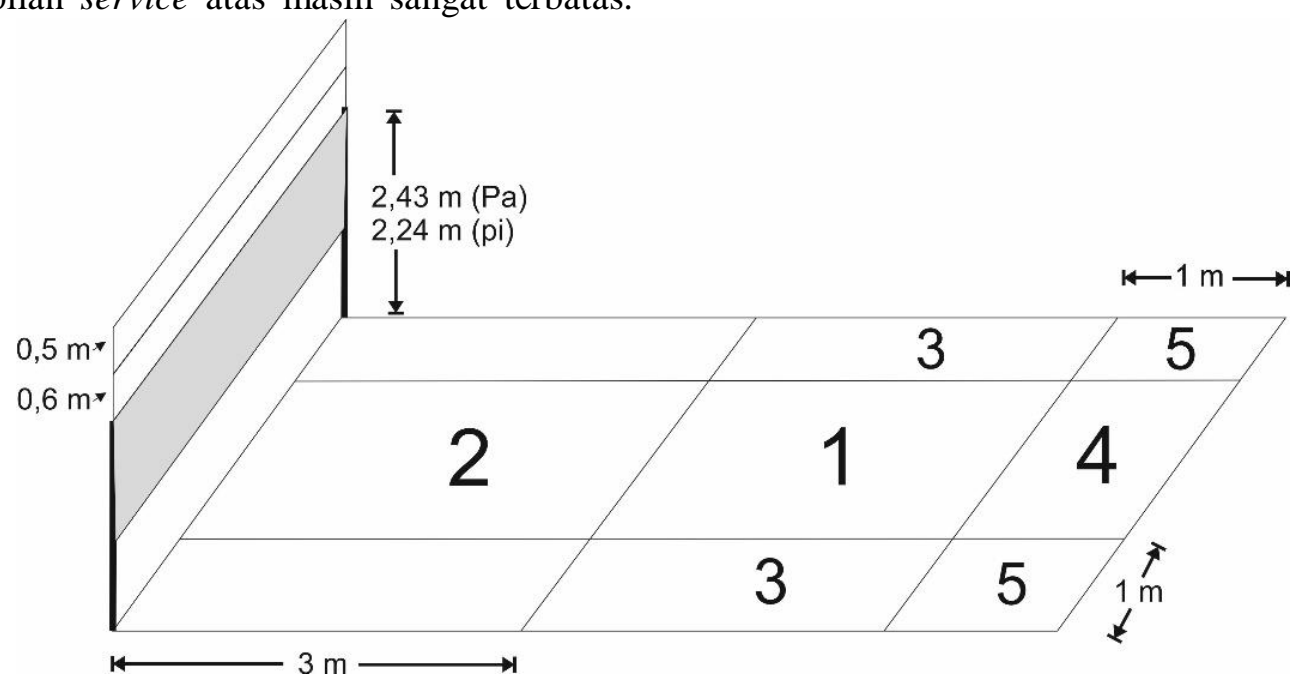

Gambar 2. Setting Lapangan Tes Service Atas

Instrumen penelitian yang digunakan dalam penelitian ini adalah tes service atas dari (Nurhasan \& Cholil, 2014, pp. 223-224). Dalam tes ini terdapat target skor yang berkisar antara 1 sampai 5. Skor 5 yang merupakan skor tertinggi terdapat di ujung kanan dan kiri lapangan voli. Sedangkan skor 1 terletak di area tengah.
Penentuan perolehan skor pada setiap kesempatan service selain berdasarkan pada letak jatuhnya bola juga berdasarkan pada jalur lintas bola saat melewati net. Apabila bola masuk diantara net dan batas pertama (batas dapat berupa tali yang dibentangkan diatas net, seperti pada Gambar 2) maka skor yang diperoleh dikali 3. Apabila bola masuk diantara batas pertama dan 
batas kedua, maka skor yang diperoleh dikali 2. Sedangkan apabila bola melewati atas batas kedua, maka skor dikali 1 atau sesuai dengan skor pada area (Angka sasaran) jatuhnya bola. Jumlah skor merupakan merupakan jumlah dari empat skor hasil perkalian terbaik (Nurhasan \& Cholil, 2014, p. 224).

Tabel 1. Bentuk Format Penilaian Tes Service Bola Voli

\begin{tabular}{|c|c|c|c|c|c|c|c|c|c|c|c|c|c|c|c|c|c|c|c|c|}
\hline \multirow{3}{*}{ No } & \multirow{3}{*}{ Nama Peserta Tes Service } & \multicolumn{18}{|c|}{ Kesempatan Service } & \multirow{3}{*}{$\begin{array}{c}\text { Jumlah } \\
\text { Skor }\end{array}$} \\
\hline & & \multicolumn{3}{|c|}{1} & \multicolumn{3}{|c|}{2} & \multicolumn{3}{|c|}{3} & \multicolumn{3}{|c|}{4} & \multicolumn{3}{|c|}{5} & \multicolumn{3}{|c|}{6} & \\
\hline & & $\mathbf{A S}$ & $\mathbf{X}$ & Skor & AS & $\mathbf{X}$ & Skor & AS & $\mathbf{X}$ & Skor & AS & $\mathbf{X}$ & Skor & AS & $\mathbf{X}$ & Skor & AS & $\mathbf{X}$ & Skor & \\
\hline 1 & Peserta 1 & 3 & 3 & 9 & 3 & 2 & 6 & 4 & 3 & 12 & 4 & 2 & 8 & 3 & 3 & 9 & 5 & 2 & 10 & 40 \\
\hline 2 & & & & & & & & & & & & & & & & & & & & \\
\hline 3 & & & & & & & & & & & & & & & & & & & & \\
\hline 4 & & & & & & & & & & & & & & & & & & & & \\
\hline 5 & & & & & & & & & & & & & & & & & & & & \\
\hline
\end{tabular}

Keterangan:

$$
\begin{array}{ll}
\text { AS } & =\text { Angka sasaran } \\
\mathrm{X} & =\text { Pengali } \\
\text { Skor } & =\text { Hasil perkalian angka sasaran dengan pengali } \\
\text { Jumlah skor } & =\text { Jumlah dari empat skor hasil perkalian terbaik }
\end{array}
$$

Apabila peserta tes pertama memperoleh angka sasaran dengan poin 3 dan mendapatkan pengali 3 (bola masuk diantara net dan batas pertama) maka skor untuk kesempatan service pertama adalah 9. Dalam contoh pada Tabel 1 empat skor terbaiknya adalah 9, 12, 9 dan 10 jumlah skor sebesar 40 .

Treatment yang diberikan berupa latihan kekuatan otot lengan dengan memanfaatkan aplikasi smartphone "Home Workout no Equipment”. Dalam aplikasi tersebut terdapat beberapa menu (Abdominal, Chest, Arm, Leg, Shoulder \& Back). Masing-masing menu latihan tersebut terdiri dari tiga tingkatan, yakni Beginner, Intermediate, dan Advance. Dalam menu latihan otot lengan pada setiap tingkatan memiliki bentuk dan jumlah gerakan yang berbeda.

Pada Arm Beginner terdiri dari 19 bentuk gerakan yang dilakukan selama 20 menit. Selanjutnya pada Arm Intermediate terdapat 25 gerakan yang dilakukan selama 26 menit. Sedangkan pada tingkat terakhir yaitu Arm Advance dilakukan selama 32 menit, sebanyak 28 bentuk gerakan. Semua bentuk gerakan yang dilakukan tanpa menggunakan beban eksternal, jadi hanya memanfaatkan beban tubuh sendiri.

Latihan menggunakan beban berat badan sendiri lebih cocok untuk membina kekuatan otot, sedangkan latihan beban dengan menggunakan
Untuk memperoleh data yang sesuai dengan pedoman pelaksanaan tes service bola voli yang digunakan, berikut ini peneliti menyajikan gambaran format penilaian tes service bola voli yang disesuaikan dengan petunjuk pelaksanaan dan cara penentuan skor. 


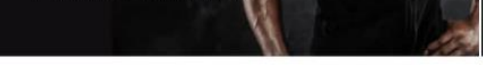

| 20 mins $\cdot 19$ workouts

I 26 mins $\cdot 25$ workouts

I 32 mins $\cdot 28$ workouts
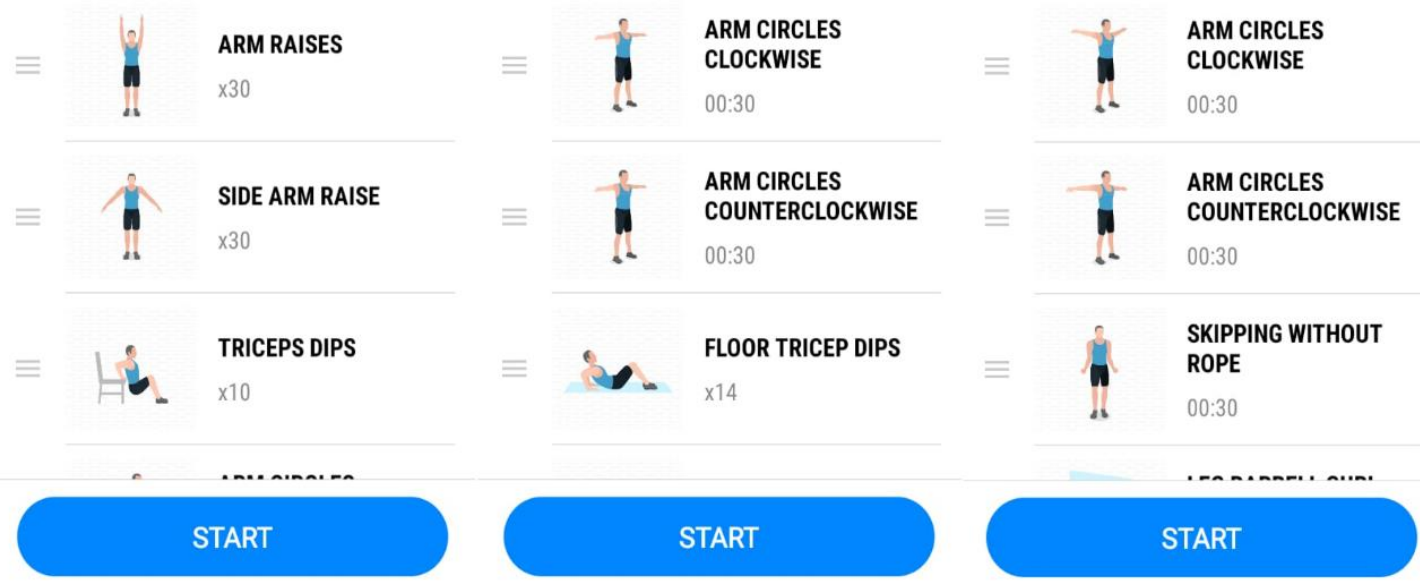

Gambar 3. Tampilan Aplikasi Smartphone Home Workout no Equipment

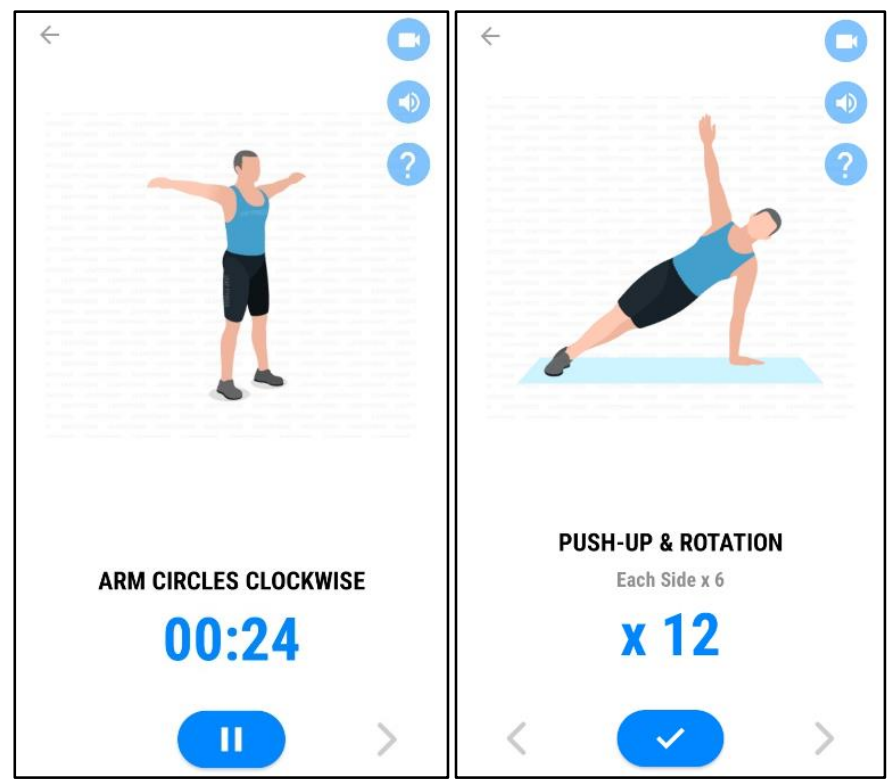

Gambar 4. Tampilan Bentuk-bentuk Gerakan Latihan

Gambar 3 merupakan tampilan menu latihan berdasarkan tingkatan, mulai dari Arm Beginner, Arm Intermediate, dan Arm Advance. Masing masing tingkatan memiliki bentuk dan jumlah gerakan latihan yang berbeda. Gambar 4 menunjukan tampilan aplikasi pada saat memulai latihan.

Gerakan ditampilkan dalam bentuk animasi yang bergerak dan dilengkapi dengan acuan yang berupa repetisi yang harus dilakukan atau waktu tertentu dalam mempertahankan suatu bentuk latihan. Setiap tampilan gerakan latihan dilengkapi dengan petunjuk suara, tombol video dan petunjuk secara deskripsi yang ditampilkan pada sudut kanan atas. Apabila melalui animasi gerakan yang telah tampil masih kurang jelas, peserta dapat menekan tombol video atau petunjuk deskripsi (tombol dengan ikon tanda tanya).

Analisis data yang dilakukan terdiri dari dua tahapan, yakni uji asumsi dan uji hipotesis. Uji asumsi atau uji prasyarat statistic dalam penelitian ini menggunakan uji normalitas melalui kormogorov smirnov $z$, dan uji homogenitas menggunakan uji variansi atau levene test. Teknik analisis yang digunakan dalam 
uji hipotesis adalah paired sample $t$ test yang digunakan untuk mengetahui pengaruh dari latihan yang diberikan, dengan menggunakan data pretest dan posttest.

\section{HASIL DAN PEMBAHASAN}

\section{Hasil Penelitian}

Penelitian yang telah dilakukan sesuai dengan jadwal penelitian menghasilkan data yang ditampilkan pada tabel berikut.

Tabel 2. Deskripsi Data

\begin{tabular}{lrr}
\hline \multicolumn{1}{c}{ Satistik } & \multicolumn{1}{c}{ Pretest } & \multicolumn{1}{c}{ Posttest } \\
\hline Rata-rata & 40,5 & 45,05 \\
Simpangan Baku & 2,30 & 3,22 \\
Skor Minimal & 37 & 41 \\
Skor Maksimal & 45 & 52 \\
Jumlah & 810 & 901 \\
\hline
\end{tabular}

Tabel 2. Menunjukan statistik deskriptif yang disajikan dalam bentuk tabel sederhana. Pada data pretest diperoleh nilai rata-rata 40,5 simpangan baku 2,3 skor minimal 37 skor maksimal 45 dan jumlah 810 sedangkan untuk data posttest diperoleh nilai rata-rata 45,05 simpangan baku 3,2 skor minimal 41 skor maksimal 52 dan jumlah 901 .

\section{Uji Asumsi}

Uji asumsi dilakukan untuk menentukan uji hipotesis yang tepat, uji statistika parametric atau non-parametrik. Apabila hasil uji asumsi menunjukan data berdistribusi normal dan bersifat homogen, maka uji hipotesis menggunakan statistika parametrik. Sedangkan apabila sebaliknya, maka uji hipotesis menggunakan statistika non-parametrik. Hasil uji normalitas yang merupakan salah satu dari uji asumsi adalah sebagai berikut.

Tabel 3. Hasil Uji Normalitas Data

\begin{tabular}{lccc}
\hline Data & $\begin{array}{c}\text { Kolmogorov- } \\
\text { Smirnov }\end{array}$ & Sig. & Keterangan \\
\hline Pretest & 0,734 & 0,654 & Data Normal \\
Posttest & 1,019 & 0,250 & Data Normal \\
\hline
\end{tabular}

Untuk data pretest diperoleh nilai KolmogorovSmirnov $=0,734$ dan Sig $=0,654>0,05$ Maka data dinyatakan normal. Pada data posttest diperoleh nilai Kolmogorov-Smirnov $=1,019$ dan
Sig $=0,250>0,05$ Maka data dinyatakan normal.

Tabel 4. Hasil Uji Homogenitas Data

\begin{tabular}{ccc}
\hline Levene Statistic & Sig. & Keterangan \\
\hline 2,401 & 0,130 & Data Homogen \\
\hline
\end{tabular}

Hasil pengujian homogenitas menunjukan nilai levene statistic $=2,401$ dan $\mathrm{Sig}=0,130>0,05$ Maka data dinyatakan homogen.

Hasil uji asumsi yang terdiri dari uji normalitas dan homogenitas menunjukan bahwa data berdistribusi normal dan bersifat homogen. Berdasarkan hasil tersebut, maka uji hipotesis dalam penelitian ini menggunakan statistika parametrik.

\section{Uji Hipotesis}

Uji hipotesis dalam penelitian ini menggunakan uji paired sample t test. Uji ini dilakukan untuk mengetahui pengaruh dari perlakuan yang diberikan, atau dapat juga disebutkan untuk menguji peningkatan dari data pretest ke posttest. Oleh karena itu, data yang digunakan dalam uji hipotsis adalah data pretest dan posttest. Hasil uji hipotesis adalah sebagai berikut.

Tabel 5. Hasil Uji Paired Sample t test

\begin{tabular}{ccc}
\hline $\boldsymbol{t}$ & Sig. & Keterangan \\
\hline 11,179 & 0,000 & Pengaruh Signifikan \\
\hline
\end{tabular}

Hipotesis:

a. Ho = Tidak terdapat pengaruh pengaruh yang signifikan latihan kekuatan otot lengan dengan memanfaatkan aplikasi smartphone terhadap peningkatan keterampilan service atas bola voli.

b. Hi = Terdapat pengaruh pengaruh yang signifikan latihan kekuatan otot lengan dengan memanfaatkan aplikasi smartphone terhadap peningkatan keterampilan service atas bola voli.

Kriteria keputusan:

a. Nilai Signifikansi atau nilai probabilitas > 0,05 , Ho diterima

b. Nilai Signifikansi atau nilai probabilitas < 0,05 , Ho ditolak

Keputusan:

Tabel 5. menunjukan nilai $\mathrm{t}=11,179$ dan $\operatorname{sig}=$ $0,000<0,05$ maka dapat diartikan terdapat 
pengaruh yang signifikan latihan kekuatan otot lengan dengan memanfaatkan aplikasi smartphone terhadap peningkatan keterampilan service atas bola voli.

\section{Pembahasan}

Data hasil penelitian yang telah melalui tahapan pengolahan dan analisis data menunjukan bahwa terdapat pengaruh yang signifikan. Lebih jelasnya dapat dinyatakan bahwa penelitian ini menunjukan bahwa pemanfaatan aplikasi smartphone "Home Workout no Equipment" yang digunakan dalam latihan kekuatan otot lengan terbukti mampu meningkatkan keterampilan service atas bola voli pada siswa putra peserta ekstrakurikuler di SMPN 1 Ciracap Kabupaten Sukabumi.

Berdasarkan hasil tersebut dapat dibahas menjadi beberapa point utama, yakni 1) Aplikasi smartphone terbukti mampu memberikan pengaruh positif terhadap hasil latihan; 2) Latihan kekuatan lengan memberikan pengaruh terhadap keterampilan service atas bola voli pada siswa tingkat SMP; 3) Bentuk-bentuk latihan pada aplikasi home work out no equipment cocok untuk digunakan untuk melatih otot lengan dan terbukti dapat meningkatkan keterampilan service atas bola voli pada siswa tingkat SMP.

Berbagai aplikasi smartphone yang berkaitan dengan keolahragaan semakin banyak bermunculan. Beberapa aplikasi smartphone tersebut diantaranya berupa pelacak kebugaran, monitor detak jantung, penghitung langkah, program latihan, dan aplikasi pembinaan (Azar et al., 2013; Peart et al., 2017). Hasil dari penelitian ini membuktikan bahwa aplikasi smartphone "Home Workout no Equipment" dapat digunakan sebagai media yang menunjang proses latihan.

Hal tersebut terjadi salah satunya karena intensitas pengunaan smartphone pada remaja yang tinggi dan pengalaman praktis penggunaan perangkat tersebut mendukung proses aktifitas fisik yang dilakukan (Palička et al., 2016, p. 176) dalam hal ini aktifitas fisik tersebut berupa latihan kekuatan otot lengan untuk meningkatkan keterampilan service atas bola voli. Aplikasi pada perangkat seperti smartphone dapat digunakan secara konstruktif untuk mendukung proses pengajaran (Krause \& Sanchez, 2014) dalam (Palička et al., 2016, p. 178). Dalam penelitian ini aplikasi smartphone digunakan untuk mendukung proses latihan pada siswa ekstrakurikuler bola voli tingkat SMP.

Pemanfaatan aplikasi smartphone memiliki potensi untuk mengubah pengumpulan data di lapangan bagi para praktisi olahraga (Peart et al., 2017). Meskipun dukungan dari hasil penelitian yang berkaitan dengan pemanfaatan aplikasi smartphone pada keolahragaan dan kesehatan masih kurang (Peart et al., 2017) akan tetapi beberapa hasil penelitian yang terkiat dengan hal tersebut beberapa waktu ini mulai bermunculan.

Seperti halnya, penelitian mengenai pemanfaatan aplikasi smartphone yang digunakan dalam latihan terbukti mampu meningkatkan $\mathrm{VO}_{2}$ Max pada pemain ekstrakurikuler futsal putri (Faozi \& Rahmawati, 2019) dan juga pada mahasiswa (Listiandi et al., 2020). Kedua penelitian tersebut memanfaatkan aplikasi smartphone Nike Traning Club yang menyediakan berbagai bentuk latihan untuk meningkatkan aktivitas fisik dan daya tahan (Faozi \& Rahmawati, 2019; Listiandi et al., 2020). Meskipun penelitian tersebut tidak secara langsung mengenai penggunaan aplikasi smartphone dalam melatih keketuan otot atau sejenisnya, akan tetapi hal tersebut memberikan suatu pertanda perkembangan arah penelitian yang salah satun fokusnya akan mengarah pada penggunaan aplikasi smartphone dalam bidang keolahragaan. Lebih luas lagi akan semakin banyak bermunculan penelitian yang mengarah pada penggunaan teknologi dalam bidang keolahragaan, khususnya di Indonesia.

Hasil penelitian ini menunjukan bahwa latihan kekuatan otot lengan dapat meningkatkan keterampilan service atas bola voli pada siswa SMP peserta ekstrakurikuler. Hasil tersebut juga serupa dengan beberapa penelitian sebelumnya. Hasil penelitian sebelumnya menyatakan bahwa terdapat hubungan positif yang signifikan antara kekuatan otot lengan dan keterampilan servis atas bola voli (Gazali, 2016; Iskandar, 2016; Pahrian \& Esser, 2017).

Service atas merupakan teknik yang tidak hanya berperan untuk memulai suatu pertandingan, akan tetapi juga sebagai serangan pertama bagi tim melalui service yang tajam dan kuat. Dalam berbagai pertandingan, termasuk liga professional bola voli tidak jarang pemain yang dapat melakukan jump service yang tajam dan kuat mampu memberikan tambahan point bagi timnya, tentunya hal tersebut merupakan sesuatu yang menguntungkan. Perolehan point dari 
service juga dikenal dengan sebutan service ace. Untuk dapat menghasilkan service atas yang baik maka salah satu faktornya adalah kekuatan otot lengan yang cukup kuat untuk memukul bola.

Mengenai kekuatan otot lengan, hasil penelitian lain juga menunjukan bahwa terdapat kontribusi yang berarti antara daya ledak otot lengan terhadap ketepatan spike siswa (Asnaldi et al., 2020). Meskipun hasil penelitian tersebut fokus pada teknik spike bukan service, akan tetapi dapat menjadi suatu indikasi bahwa kekuatan otot memberikan suatu kontribusi pada keterampilan teknik dasar bola voli.

Berbagai bentuk latihan yang terdapat dalam aplikasi smartphone "Home Workout no Equipment" yang diterapkan sesuai dengan rancangan penelitian menunjukan hasil yang positif. Seluruh bentuk latihan yang terdapat dalam aplikasi smartphone tersebut merupakan berbagai bentuk gerakan yang bervariasi dengan memanfaatkan beban berat tubuh sendiri.

Berkaitan dengan hal tersebut, terdapat 2 jenis penggunaan beban, yaitu bebab bebas (Free weight) dan beban berat badan sendiri (Suharjana, 2007, p. 87). Dalam penelitian ini tujuan latihan adalah untuk melatih kekuatan otot lengan, sedangkan sampel yang digunakan adalah siswa putra peserta ekstrakurikuler yang bukan merupakan atlet profesional. Untuk memenuhi tujuan latihan tersebut (kekuatan otot lengan) berkaitan dengan penggunaan beban, latihan yang tepat adalah menggunakan beban berat tubuh sendiri (Suharjana, 2007, p. 87). Sedangkan penggunaan beban bebas lebih cocok digunakan oleh peserta latihan yang sudah berpengalaman / atlet (Suharjana, 2007, p. 87).

Bentuk latihan yang terdapat dalam aplikasi smartphone "Home Workout no Equipment" yang digunakan berdasarkan pemaparan tersebut sesuai dengan tujuan latihan dan juga tepat untuk digunakan oleh siswa putra peserta ekstrakurikuler pada tingkat SMP. Menu dan tampilan pada aplikasi juga mudah untuk dipahami oleh para siswa. Setiap bentuk gerakan latihan ditampilkan dalam bentuk animasi gerakan, hal tersebut membuat siswa lebih tertarik untuk menyelesaikan latihan sesuai dengan petunjuk yang tampil.

Petunjuk mengenai gerakan-gerakan yang harus dilakukan selain didukung dengan animasi bergerak juga terdapat petunjuk suara, video gerakan dan narasi deskripsi. Meskipun penerapan aplikasi smartphone dalam latihan bola voli pada siswa ektrakurikuler SMPN 1 Ciracap Kabupaten Sukabumi merupakan hal yang baru, akan tetapi sebagian besar siswa sangat mudah memahami cara penggunaan aplikasi smartphone Home Workout no Equipment. Hal tersebut terjadi karena pada dasarnya para siswa sudah sangat terbiasa menggunakan smartphone, meskipun digunakan untuk kegiatan lain.

Secara keseluruhan hasil penelitian ini menunjukan bahwa penggunaan atau pemanfaatan aplikasi smartphone dapat diterapkan untuk menunjang latihan suatu cabang keolahragaan. Terlebih lagi saat ini semakin banyak developer yang mengembangkan berbagai aplikasi smartphone khusus dalam bidang olahraga dan juga kesehatan.

Meskipun sejumlah aplikasi telah divalidasi, akan tetapi sebagai praktisi olahraga juga harus dapat bersikap kritis dan memilah aplikasi smartphone yang tepat untuk digunakan dalam suatu latihan tertentu (Peart et al., 2017). Dengan pesatnya perkembangan teknologi dalam berbagai bidang, praktisi olahraga juga harus dapat berupaya lebih untuk memanfaatkan perkembangan teknologi tersebut pada praktik keolahragaan.

\section{KESIMPULAN}

Berdasarkan hasil dan pembahasan penelitian menunjukan bahwa latihan kekuatan otot lengan dengan memanfaatkan aplikasi smartphone mampu meningkatkan keterampilan service atas bola voli pada siswa peserta ekstrakurikuler SMPN 1 Ciracap Kabupaten Sukabumi.

Penelitian ini menunjukan bahwa aplikasi yang digunakan pada smartphone dapat diintegrasikan dalam latihan keolahragaan, dalam hal ini latihan kekuatan otot lengan untuk meningkatkan keterampilan service atas bola voli. Penelitian ini dapat menjadi suatu langkah awal dalam mengintegrasikan berbagai aplikasi berbasis smartphone atau sejenisnya, bahkan merancang suatu aplikasi yang dapat menyelesaikan berbagai permasalahan dalam bidang keolahragaan. 


\section{DAFTAR PUSTAKA}

Asnaldi, A., Ilmu, F., Universitas, K., Padang, N., Ledak, D., Lengan, O., Smash, K., \& Voli, B. (2020). Hubungan Kelentukan dan Daya Ledak Otot Lengan Terhadap Ketepatan Smash Bolavoli. Physical Activity Journal, 1(2).

Azar, K. M. J., Lesser, L. I., Laing, B. Y., Stephens, J., Aurora, M. S., Burke, L. E., \& Palaniappan, L. P. (2013). Mobile applications for weight management: Theory-based content analysis. American Journal of Preventive Medicine, 45(5), 583589.

https://doi.org/10.1016/j.amepre.2013.07.00 5

Edwan, Sutisyana, A., \& Ilahi, B. R. (2017). Pengaruh Metode Latihan Plyometric Terhadap Kemampuan Jumping Smash Bola Voli Siswa Ekstrakurikuler SMPN 1 Bermani Ilir Kabupaten Kepahiang. KINESTETIK: Jurnal Ilmiah Pendidikan Jasmani, 1 (1) 2017, 1(1), 64-67.

Faozi, F., \& Rahmawati, D. (2019). Pengaruh Penggunaan Aplikasi Nike Training Club Terhadap Peningkatan Vo2max Pada Pemain Ekstrakurikuler Futsal Putri Man 1 Kabupaten Sukabumi. Biormatika: Jurnal Ilmiah Fakultas Keguruan Dan Ilmu Pendidikan, 5(02), 181-187. https://doi.org/10.35569/biormatika.v5i02.5 19

FIVB. (2016). Official Volleyball Rules 20172020 (pp. 1-84). FIVB in 2016 www.fivb.com.

Gazali, N. (2016). Kontribusi Kekuatan Otot Lengan Tehadap Kemampuan Servis Atas Atlet Bolavoli. Journal of Physical Education, Health and Sport, 3(1), 1-6. https://doi.org/10.1016/j.ejogrb.2012.06.022

Iskandar. (2016). Servis Atas Bola Voli Mahasiswa Putra Penjaskes Ikip-Pgri Pontianak. Jurnal Pendidikan Olahraga, 5(1), 20-28.

Listiandi, A. D., Kusuma, M. N. H., Budi, D. R., Hidayat, R., Bakhri, R. S., \& Abdurahman, I. (2020). Pemanfaatan Aplikasi Smartphone untuk Meningkatkan Daya Tahan Kardiovaskuler dan Self-efficacy. Jendela Olahraga, 05(2), 9-17.

Maksum, A. (2012). Metodologi Penelitian dalam Olahraga. Universitas Negeri Surabaya.

Muflih, M., Hamzah, H., \& Puniawan, W. A. (2017). Penggunaan Smartphone Dan Interaksi Sosial Pada Remaja di SMA Negeri 1 Kalasan Sleman Yogyakarta. Idea Nursing Journal, VIII(1), 12-18.

Nurhasan, H., \& Cholil, D. H. (2014). Tes Dan Pengukuran Keolahragaan. Fakultas Pendidikan Olahraga dan Kesehatan, Universitas Pendidikan Indonesia.

Pahrian, A., \& Esser, B. R. N. (2017). Hubungan Kekuatan Otot Lengan Terhadap Ketepatan Servis Atas. GELORA: Jurnal Pendidikan Olahraga Dan Kesehatan, 4(2), 66-69.

Palička, P., Jakubec, L., \& Zvoníček, J. (2016). Mobile apps that support physical activities and the potential of these applications in physical education at school. Journal of Human Sport and Exercise, 11(Special issue 1), S176-S194. https://doi.org/10.14198/jhse.2016.11.Proc1. 08

Peart, D. J., Balsalobre-Fernández, C., \& Shaw, M. P. (2017). Use of Mobile Applications to Collect Data in Sport, Health, and Exercise Science: A Narrative Review. Journal of Strength and Conditioning Research, 33(4), 1167-1177. https://doi.org/10.1519/JSC.0000000000002 344

Suharjana. (2007). Latihan Beban: Sebuah metode Latihan Kekuatan. Jurnal Ilmiah Kesehatan Olahraga, 3(1), 80-101. 